膵仮性整胞の破裂が原因と思われた腹腔内出血の 1 例

横須賀市立市民病院外科

亀田久仁郎久保章野村直人野尻和典

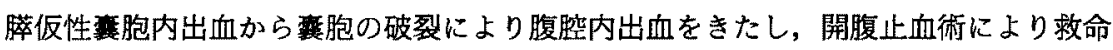
しえた 1 例を経験した。症例は 32 歳，女性。他院入院中突然の上腹部痛と意識混濁を認 めショック状態となり，原因不明の腹腔内出血の診断で当院へ転送された，緊急開腹術 を施行したところ，膵尾部の一部から拍動性の出血が確認された，その周囲には蕒胞壁 と思われる組織の残骹が認められた。出血部分を中心として 4 針程膵実質を縫合すると 止血されたため, 膵切除は施行せず閉腹した. 出血量は $4,800 \mathrm{ml}$ であった. 術後経過は良 好で第15病日に退院した。現在までに再出血は認めていない，膵仮性靵胞の合併症のな かでも腹腔内出血は非常に稀であり, 本邦報告例は検索し得る限りでは16例のみである. 若干の文献的考察を加えてこれを報告する。

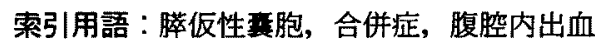

はじめに

急性・慢性を問方ず膵炎に伴って形成される仮性蛮 胞は種々の合併症を引き起こす可能性を秘めている. その中でも腹腔内出血は, 頻度は高くないが時に大量 出血をきたして重大な合併症となり得る，今回われわ れは，膵仮性㯎胞の裹胞内出血およびその破裂に起因 すると思われる大量の腹腔内出血を認め, 開腹止血術 により救命しえた症例を経験したのでこれを報告す る.

患者：32歳, 女性.

\section{症例}

主訴：上腹部痛.

家族歴：特記すべきことなし。

既往歴：特記すべきことなし。

㖺好品：ビール小㧚1本／日を $2 \sim 3$ 回／週.

現病歴: 平成15年 1 月16日昼過ぎより腹部痛が出 現した，夜になっても疼痛持続するため，近医受診し 急性膵炎の疑いで入院となった。 1 月17日午後 2 時 30 分頃より急激な痛みの增強と同時に意識混潈, 血圧低 下を認めたため,頭部㧍よび腹部 CTを施行した結果， 原因不明の腹腔内出血と診断された。ショック状態と

2003年 4 月 30 日受付 2003 年 9 月17日採用

〈所属施設住所〉

于240-0195 横須賀市長圾 $1-3-2$
なり，抻管後当院へ救急車にて転送された，午後 5 時 48分当院に到着し, 午後 6 時 58 分に緊急開腹術を施行 した.

入院時身体所見：救急車中にて輸血 (MAP 6 単位) を施行し来院した，挿管下自発呼吸 (O $281 / \mathrm{min})$ に て SaO 2 100\%. 意識レベルはJCS IIIにて20-A であ った. 体温 $36.8^{\circ} \mathrm{C}$, 血圧 $78 / 53 \mathrm{mmHg}$, 脈拍 $107 / \mathrm{min}$, 腹部は軽度膨隆を認め，眼瞼結膜には䆩血を認めた。

入院時検查所見 (表 1 ): 白血球 $24,200 / \mu \mathrm{l}, \mathrm{Hb} 8.0$ $\mathrm{g} / \mathrm{dl}$, Hct 23.1\%，と貧血扔よび感染徵候が認められ た。血中アミラーゼ値は1,169IU/1 と著しい上昇を認 めた。

術前腹部単純 CT 検查（図 1)：腹腔内には多量の 腹水貯留を認めた。膵缄は全体的にやや腫大を認め, 尾部に $3.5 \mathrm{~cm}$ 大の低吸収域を認めた。全身状態不良て あり，早急な開腹止血処置が必要と思われたため，午 後 6 時 40 分手術室に入室し午後 6 時 58 分執刀となっ た.

術中所見（図 2 ）：開腹し腹腔内を観察すると,多量 の出血が認められた，出血は腹腔内全体にわたって䛊 められたが，上腹部に優位であった。更に検索すると， 脾下極近くの大網内に血缠形成を認めた。この部分を 切開してみると，膵尾部の方向から血液の流出が認め られた．脺周囲には炎症性変化と思われる癒着が認め られ，脺実質はやや固く触知した，脾葴および脺体尾 


\section{表 1 入院時検查所見}

\begin{tabular}{|c|c|}
\hline WBC $24,200 / \mu \mathrm{I}$ & BUN $13.7 \mathrm{mg} / \mathrm{dl}$ \\
\hline RBC $248 \times 10^{4} / \mu 1$ & $\mathrm{Cr} \quad 0.9 \mathrm{mg} / \mathrm{dl}$ \\
\hline $\mathrm{Hb} \quad 8.0 \mathrm{~g} / \mathrm{dl}$ & $\mathrm{Na} \quad 136 \mathrm{mEq} / \mathrm{l}$ \\
\hline Hct $23.1 \%$ & $\mathrm{~K} \quad 3.7 \mathrm{mEq} / 1$ \\
\hline Plt $25.2 \times 10^{4} / \mu \mathrm{l}$ & $\begin{array}{l}\mathrm{Cl} 101 \mathrm{mEq} / \mathrm{l} \\
\mathrm{TP} \quad 3.9 \mathrm{~g} / \mathrm{dl}\end{array}$ \\
\hline GOT $37 \mathrm{IU} / 1$ & Alb $2.5 \mathrm{~g} / \mathrm{dl}$ \\
\hline GPT $26 \mathrm{IU} / 1$ & CRP $\quad 0.06 \mathrm{mg} / \mathrm{dl}$ \\
\hline $\mathrm{LDH} 319 \mathrm{IU} / \mathrm{l}$ & \\
\hline AMY $1,169 \mathrm{IU} / \mathrm{l}$ & PT $14.8 \mathrm{sec}$ \\
\hline FBS $112 \mathrm{mg} / \mathrm{dl}$ & APTT $20.3 \mathrm{sec}$ \\
\hline CPK $378 \mathrm{IU} / 1$ & \\
\hline
\end{tabular}

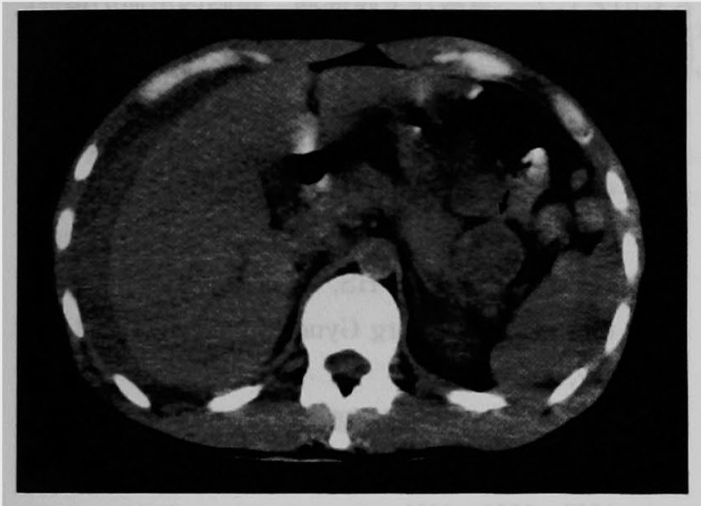

図 1 術前腹部単純 CT 検查：右横隔膜下に腹水貯留を 認めた. 膵尾部には径 $3.5 \mathrm{~cm}$ 大の腫瘤状病変 (矢印) を 証めた。

部を後腹膜から脱転したのちに再度観察すると, 犦胞 壁であったと思われる組織片が残存している膵尾部の 一部から拍動性の出血が確認された。この部分を中心 に，脺の長軸と垂直方向に膵実質を 4 針縫合したとこ ろ止血が得られた．腹腔内を充分検索したが他に出血 源は認められなかったため，洗浄後閉腹とした。術中 出血量は $4,800 \mathrm{ml}$ であった。

術後経過：第 1 病日に抜管し，第 5 病日に経口摄取 を開始した。術後経過は順調で第15病日に退院となっ た. 術後 2 週目に施行した腹部造影 CT 検查（図 3 ） では脺臓の軽度腫大を認めるのみであり，ERCP（図

4) では主膵管の異常所見は認められず，明らかな合 流異常も認めなかった，現在外来通院中であり，腹痛 もなく血液生化学的検查でも特に異常は認めていな w.

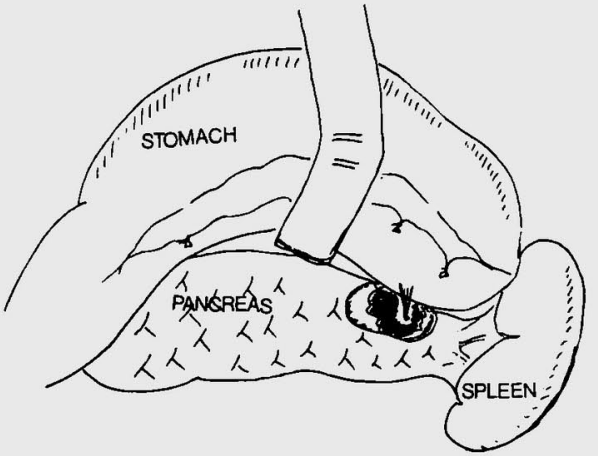

図 2 術中所見：毫胞壁であったと思われる組 織片が残存している膵尾部の一部から, 拍動性 の出血を認めた。

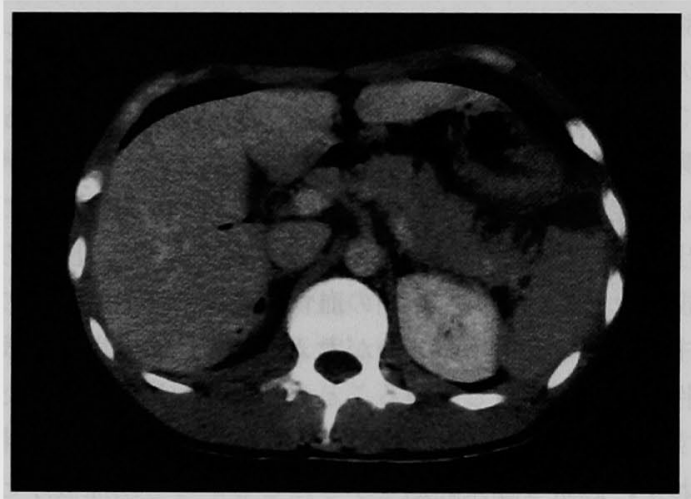

図 3 術後腹部造影 CT 検査：膵臟は全体的に腫大して いたが，新たな篗胞の出現は認めなかった。

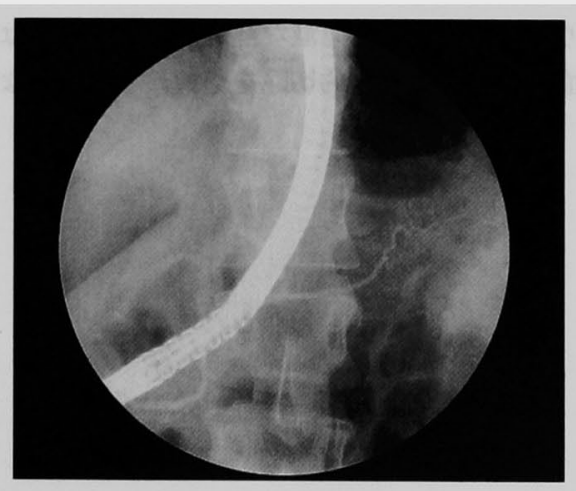

図 4 術後 ERCP : 主膵管に拡張・蛇行など の変化は認められなかった。また，膵胆管合 流異常も認められなかった。 
考察

膵仮性亯胞は膵臓の炎症性変化の結果として, 膵か らの㑢出液が脺周国に限局性に貯留した状態と考えら れ，慢性もしくは急性脺炎の10〜15\%に発生すると報 告されている”．自然消腿もあり得るが種々の合併症 を引き起こす場合もある。この際, 状態の安定した慢 性脺炎に伴う仮性䧶胞よりも，急性脺炎や慢性膵炎急 性憎悪に続発する不安定で未熟な仮性焦胞の方が, 内 容物の組織刺激性も強くより合併症をきたしやすい. 合併症として報告されているものには感染による膿瘄 形成, 穿通・破裂, 出血, 消化管・胆管などの閉塞が ある.このうち出血は稀な合併症であり, Becker ら2 は全合併症のうち10\%であったと報告している，仮性

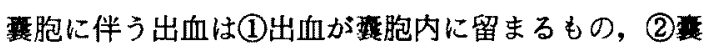
胞出血後膵管や瘦孔を通して近接消化管に出血するも の，(3)豪胞が出血後破裂し腹腔内出血を起こすものの 3つに大別される. 本症例は(3)の type であるが，その 頻度は咅胞内出血例の中でも最も少なく, 本邦報告例 は本症例を含めて16例にすぎない3．また，腹腔内への 出血例の致死薪は $47 \%$ とも報告されている4. 出血の 機序としては(1)䧶胞壁内の血管の破綻，(2)垔胞近傍の 主要血管の出血, の2つが考えられる. (2)の場合は仮 性動脈瘤が先行していることが多く, 大量出血をきた すこともあり得る゙!. 本症例が慢性的炎症性変化を伴 わず，急激な臨床経過を示したことからも出血機序と しては(2)の可能性が高いと思われる. 止血方法として は選択的血管造影下の動脈塞栓術 (TAE) やコイルに よる止血が第 1 選択と思われるが，止血困難例や出血 を繰り返すもの，また急激な経過をとるものでは，事 胞と血管を含めた外科的切除を選択せざるを得ない.
本症例は開腹時の出血量も多く全身状態も悪かったた め可能な限り手術侵䘫を小さくしたかった。また，32 歳と年柃も若く，臟器温存ができればという考えもあ り膵切除は行わず, 縫合止血のみを施行した. 現在ま で特に問題はないが，仮性動脈瘤形成後の出血とする と今後再出血のリスクは十分あり，血管造影検査を含 め慎重なフォローアップが必要であると思われる。再 度膲胞出現の場合は積極的な切除の適応と思われる。

\section{結 語}

急性膵炎に伴う仮性亯胞の破裂が原因と思われる， 腹腔内出血の 1 例を経験したのてこれを報告した，仮 性豪胞破裂・出血は若年者で飲酒歴軽度でも起こりう るものとして, 急激な上腹部痛, 腹腔内出血の場合に は鑑別診断に加えなければならないと思われた。

\section{文献}

1）坂東隆文,八巻 隆, 磯山 徹他: 膵仮性犦胞内 に出血した左胃大網動脈仮性動脈瘤の 1 例. 胆と 脺 $13: 329-334,1992$

2) Becker WF, Pratt HS, Ganji H : Pseudocyst of the pancreas. Surg Gynecol Obstet $127: 744-$ 747,1968

3）村上慶洋, 岩井和浩, 高田実他：腹腔内出血を きたした膵仮性鹿胞の1例。日臨外会誌 62 ： 1755-1758, 2001

4) Sankaran S, Walt AJ : The natural and unnatural history of pancreatic pseudocyst. $\mathrm{Br}$ J Surg $62: 37-44,1975$

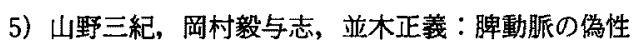
動脈瘤穿破による膵仮性蒦胞内出血の 1 例. Gastroenterol Endosc $30: 1255-1268,1988$ 


\title{
A CASE OF INTRAABDOMINAL BLEEDING PROBABLY CAUSED BY RUPTURE OF A PANCREATIC PSEUDOCYST
}

\author{
Kunio KAMEDA, Akira KUBO, Masato NOMURA and Kazunori NOJIRI \\ Department of Surgery, Yokosuka Citizens' Hospital
}

We successfully saved a patient with intraabdominal bleeding caused by rupture of a pancreatic pseudocyst with resultant intracystic hemorrhage by performing hemostatic procedure under laparotomy.

A 32-year-old woman, who had abrupt onset of upper abdominal pain and clouding of consciousness and went into shock during hospitalization elsewhere, was transferred to the hospital with a diagnosis of intraabdominal bleeding of unknown origin. Emergency laparotomy disclosed pulsating bleeding from a part of the pancreatic tail and tissue debris surrounding the part which seemed like cystic wall. With four stitches of the pancreatic parenchyma around the bleeding site, hemostasis was attained so that the abdomen was closed without pancreatic resection. The operative bleeding amounted to $4800 \mathrm{ml}$. The postoperative course was uneventful and the patient was discharged from the hospital on the $15^{\text {th }}$ hospital day. No bleeding has occurred up to now.

Intraabdominal bleeding is a rare complication of pancreatic pseudocyst, and only 16 cases have been reported in Japan as far as we could review. This paper presents the case together with some bibliographical comments. 